\title{
The Management of School Libraries Muhammadiyah
}

\author{
Mutia Febriyana, Nadra Amalia, Deliati \\ University of Muhammadiyah Sumatera Utara \\ mutiafebriyana@umsu.ac.id
}

\begin{abstract}
The purpose of this activity is to realize a superior and competitive rotation management program. Partners in this activity are Muhammadiyah Schools in Sukaramai and PCM Tegal Sari II PCM. The existence of Muhammadiyah schools is equipped by school libraries as a means of supporting the success of student learning. As one of the sources of learning in schools, libraries help achieve the vision and mission of the school. Given the importance of the school library, it is necessary to have an appropriate and fast management or management so that the function of the school library really materializes. Library management at Muhammadiyah schools in PCM is still not implemented in accordance with library management standards based on Minister of National Education Regulation No. 25/2008 concerning Library Staff Standards for Schools / Madrasas. However, the problem found is that not a few libraries whose management is not yet professional. This is because the understanding of school librarians still does not understand about managing the school library properly. The target to be achieved through this PKPM activity is the development of a superior and competitive management of Muhammadiyah school libraries. The method of implementation was (1) musyawarah preparation with PCM partners Sukaramai and PCM Tegal Sari II, (2) Implementation (actions) of the management of Muhammadiyah school library management, (3) observation of Muhammadiyah school library management, (4) Library Management Development Evaluation, and (5) Reflections on Muhammadiyah School Librarians.
\end{abstract}

Keywords-Management; Library; Muhammadiyah School

\section{INTRODUCTION}

Library is a valuable asset in the process of educating the community. It is also stated in the expression of Ray Douglas Bradbury in Achmad (2014) that "without what library do we have? We don't have a past and we don't have a future either. This expression can be understood because the role of libraries is very meaningful in encouraging the life of the nation.

So, the researchers broke the role of the library through librarian management so that the librarian profession can build a good self-image as a librarian profession getting better. At the same time diminish the notion that librarians are second class compared to other professions such as judges, doctors, and building experts. Besides that, found in Nugrohoadhi (2016) the bad image for librarians in the past, will corner the role of librarians. The impact is that librarians become frustrated because the library's operational capability is burdened by internal problems that plague the library.

The basis of this study managing library staff to be more independent in schools. Through this activity, librarians who have been fostered will become professionals and can realize school goals through library science. Of course the library of school must carry out the functions that are attached to it as well as possible. The functions that the school library must implement are Suhendar (2014), as follows:

1. Preparation of a library work plan that will be carried out for one year.

2. Preparation of plans for procurement of library materials to be used in the library.

3. The procurement of printed and non-printed library materials that can directly or indirectly support learning.

4. Implementation of library material management.

5. Implementation of the preparation and arrangement of library materials

6. Implementation of cooperation with teachers in the provision of library materials to be used in learning.

7. Implementation of student reading interest guidance.

8. Preparation of library rules

9. Organizing library services.

10. Organizing library service administration.

11. Implementation of library promotion

12. Implementation of library administration.

13. Implementation of library user guidance

14. Implementation of reporting on library operations.

Muhammadiyah is the largest Islamic organization in Indonesia. The main objective of Muhammadiyah is to restore all deviations that occur in the process of proselytizing. The Muhammadiyah movement is characterized by the spirit of building a more advanced and educated social system and education. Implementing Islamic teachings is not just a religion that is static but dynamic and acts as a system of human life in all its aspects. One form of realization through 
the establishment of schools throughout Indonesia, especially the city of Medan. Muhammadiyah schools are scattered in many branches, one of which is PCM Sukaramai and PCM Tegal Sari II. Founded schools play an active role in building national civilization through literacy activities, thus creating literary human resources in Muhammadiyah schools through the existence of school libraries as learning resources.

The establishment of a school library is an important foundation whose existence is very influential on the progress of the nation's children. This is in line with Lasa's statement (2009) that, "The existence of a school library is expected to be able to function as a media for learning places, simple research, utilization of technology, information, alternative classes and sources of information." If schools are able to manage the library properly it is not impossible The library can function as Lasa's opinion can more or less affect the human resources in the school.

The development of a library must be carried out based on the policies of the shade institution, except if the library is independent. The main basis that must be the foundation is the institution's vision and mission. The library must play a role in supporting the achievement of this vision and mission. An independent library must also have a vision and mission to be used as a foothold for development. With a clear vision and mission, a measure or indicator of success that must be achieved in development can be made. For example and penung libraries continually, it should be able to create conditions of cooperation that support the development of libraries so that everything can become a standard library that must be guided by Minister of National Education Regulation No. 25 of 2008 concerning Standards for Library / Madrasah Library Personnel. The standard library includes: standard librarian HR and administrative staff, service standards (types and forms of services); user coverage (local communities - regional national - etc.); supporting facilities (buildings and tools). Priority is given to the components that best support the institution's development targets.

The fostered school is a target school from the Sukaramai PCM and Tegal Sari II PCM to realize a superior and competitive rotation management program. PCM Sukaramai consisted of Muhammadiyah 07 Elementary School, Muhammadiyah 58 Middle School, and Muhammadiyah 06 Vocational School in Medan Area. PCM Tegal Sari II consists of Muhammadiyah 03 Elementary School and Medan Denai 05 Muhammadiyah Middle School. The distance of the partner location is not far from the Muhammadiyah University of North Sumatra environment because the location of the library management development training will be held in one of the partner schools having its address at Jalan Bromo Gg. Safe 38 Medan Denai District. This close location is expected to facilitate coordination and the activities of the Tri Dharma Perguruan Tinggi, namely the dedication of community affairs aimed at improving the welfare of women with disabilities in North Sumatra.

Based on the results of the analysis, there were several results of discussions with the two partners, namely the Chairperson of PCM Sukaramai, Chairperson of PCM Tegal Sari II and Principal with the results of in-depth discussion with the teacher on several observations made in October 2017, there were several problems that needed non-guidance economics in schools, namely: (1) The state of the library is not sufficient as a school library. (2) Library management has not been implemented in accordance with library management standards. (3) Library managers (librarians) are still limited to the managerial ability of the library because librarians are not experts in the library field, but subject teachers who carry out duties as school library librarians.

This PKPM activity is expected to provide benefits for Muhammadiyah Branch Manager Partners, namely fostering library managers in the implementation of libraries and establishing cooperative relationships between UMSU and Muhammadiyah Schools and can help understand and solve problems faced by school leaders and library managers.

\section{The Problem of Study}

\section{METHODS}

Based on the results of the service carried out by the PKPM Implementation Team as described in the introduction, it can be concluded that the partner problem solving framework is as follows:

1. Preparing deliberations with PCM Sukaramai and PCM Tegal Sari II partners, including recording the number of library management coaching participants, preparing a number of training equipment, and designing training and coaching activities for library managers.

2. Carry out management coaching actions in the Muhammadiyah School library, namely holding library management training, Islamic and Kemuhammadiyahan library management, library management and practice of implementing library management.

3. Carry out management observations of the Muhammadiyah School library.

4. Carry out an evaluation of the management of the Muhammadiyah School library.

5. Reflecting with Muhammadiyah School Librarians.

\section{Realization of Problem Solving}

Based on the problem solving framework, the realization given to solving partner problems is as follows:

1. Preparation of the initial activities on Monday, March 26, 2018 carried out by the implementing team of lecturers together with the Principal of PCM Sukaramai and PCM Tegal Sari II along with the Leaders of PCM 
Sukaramai and Tegal Sari II. This activity is a visit to school as a pre-action. The pre-action activities carried out included discussing the school library management system at the Muhammadiyah PCM Sukaramai and Tegal Sari II Schools, observing the condition of the school library, documenting the school library in the form of photos, and conducting unstructured interviews with teachers who served as school library managers. This activity discusses the management of the Muhammadiyah School library to realize the superior and competitive management of the Muhammadiyah School library.

2. The PKPM implementation team carries out the Management of Muhammadiyah School Library Management activities in Medan Denai Middle School Muhammadiyah 05 Jalan Bromo Gg. Aman Medan together with 2 students. This activity was irrigated by principals and teachers who served as managers of the Muhammadiyah school library. This coaching activity was facilitated by speakers who were experts in library management. The implementation team brought 2 UMSU library staff to help provide scientific insights related to library management. Coaching activities are filled with question and answer discussions.

3. The realization of the observation activities of the management of Muhammadiyah School library management is carried out through library management practices. The participants were facilitated by a number of library processing practices and independently worked in groups. In addition, partners who are fostered must also meet the management aspects of library management including: (1) Schools form the organizational structure of school libraries in each unit .. (2) All components of school citizens (especially students) are involved in literacy and library activities, (3) Continuously coordinating school management and processing.

4. Realiation of the evaluation of Muhammadiyah School library management coaching was carried out by evaluating the Muhammadiyah School library development activities with some meeting material that had been socialized by the lecturer implementing team and library experts as well as discussing further plans as a follow-up to the embodiment of Muhammadiyah School library management. This activity was also evaluated through the Muhammadiyah School library development checklist.

5. Reflecting on Muhammadiyah school library development activities.

The outputs generated from this coaching activity are:

1. There are library management staff who are proficient in the management of the school library. In other words, the subject matter teacher who has additional duties as a manager can have special competence in the management of the Muhammadiyah school library.

2. The Muhammadiyah schools that are fostered can implement a Muhammadiyah school management management system in accordance with the school library management standards.

3. Muhammadiyah schools that are fostered can realize superior and competitive library management.

\section{Target Audience}

Mitra I in this service is PCM Sukaramai and partner II is PCM Tegal Sari II. The partners were chosen with the aim of being complementary partners, both PCM as the embodiment of the educational institutions that were targeted through the management activities of the Muhammadiyah school library, as a basic debriefing related to the management of school library management and school library processing. Not only that, departing from the analysis of the problems found, the Service Implementation Team also involved library experts who helped the school library management activities.

\section{Implementation Method}

Based on the partner problems described above, the PKPM method used is as follows:

1. Using comprehensive training methods to realize superior and competitive library management.

2. Utilizing competent and professional tutor HR in the library field and empowering teachers and principals as a team to manage the school library.

3. Providing solutions to problems faced by partners related to school library management.

\section{FINDING AND DISCUSSION}

The service program focuses on managing the school library. Based on the results of initial coordination with the two partners namely PCM Sukaramai and PCM Tegal Sari II, there was an agreement to hold this coaching activity. This is intended so that the teacher carrying out the task as manager of the Muhammadiyah school library has scientific insight and skills in managing the school library.

Coaching activities are held on Friday, May 112018 until Saturday, May 12, 2018 at the Muhammadiyah 05 Medan Medan Denai Middle School. This PKPM activity was attended by PWA DIKDASMEN and all principals and school library managers from PCM Sukaramai and PCM Tegal Sari II as shown in the following figure: 


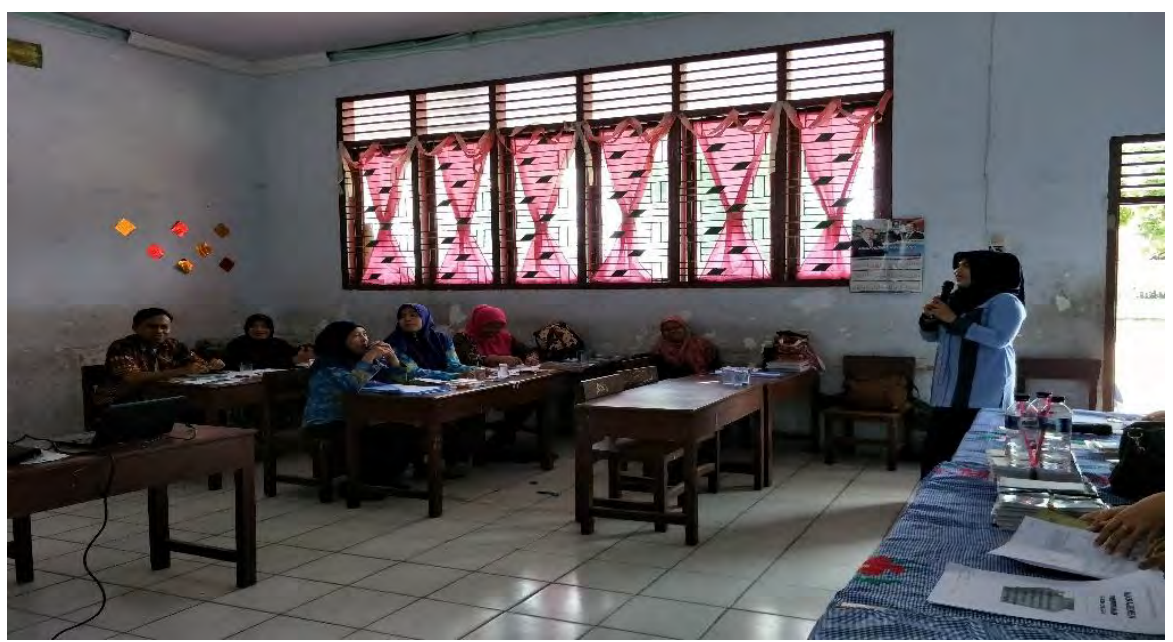

Figure 1. The Chairperson of PKPM is giving a speech at the Management of Muhammadiyah School Library Management Activities

Not only that, in the coaching activity. The trained participants are provided with material by competent and professional tutors in the library field. The tutors provide material related to school library management and library material processing. After that, the participants were given direct practice in managing the library, the participants seemed enthusiastic in listening to the discussion of the material and carrying out the practices presented by the Tutor as shown in the following figure.
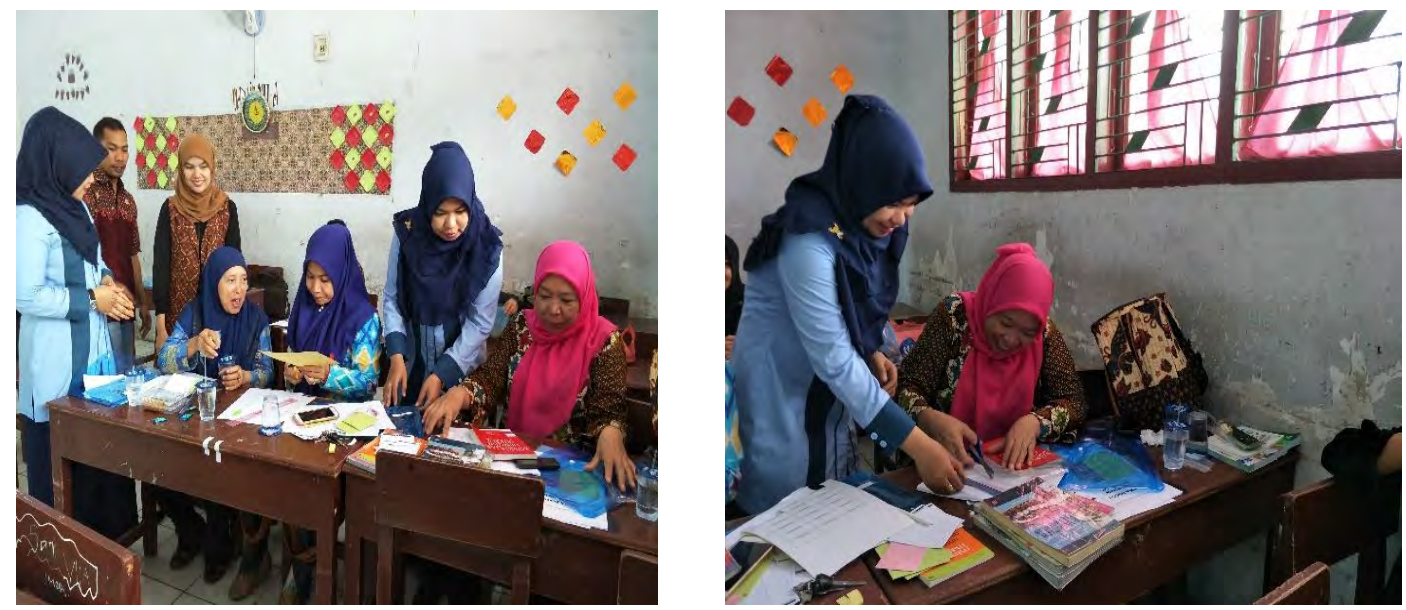

Figure 2. The learning atmosphere of library material processing practices 


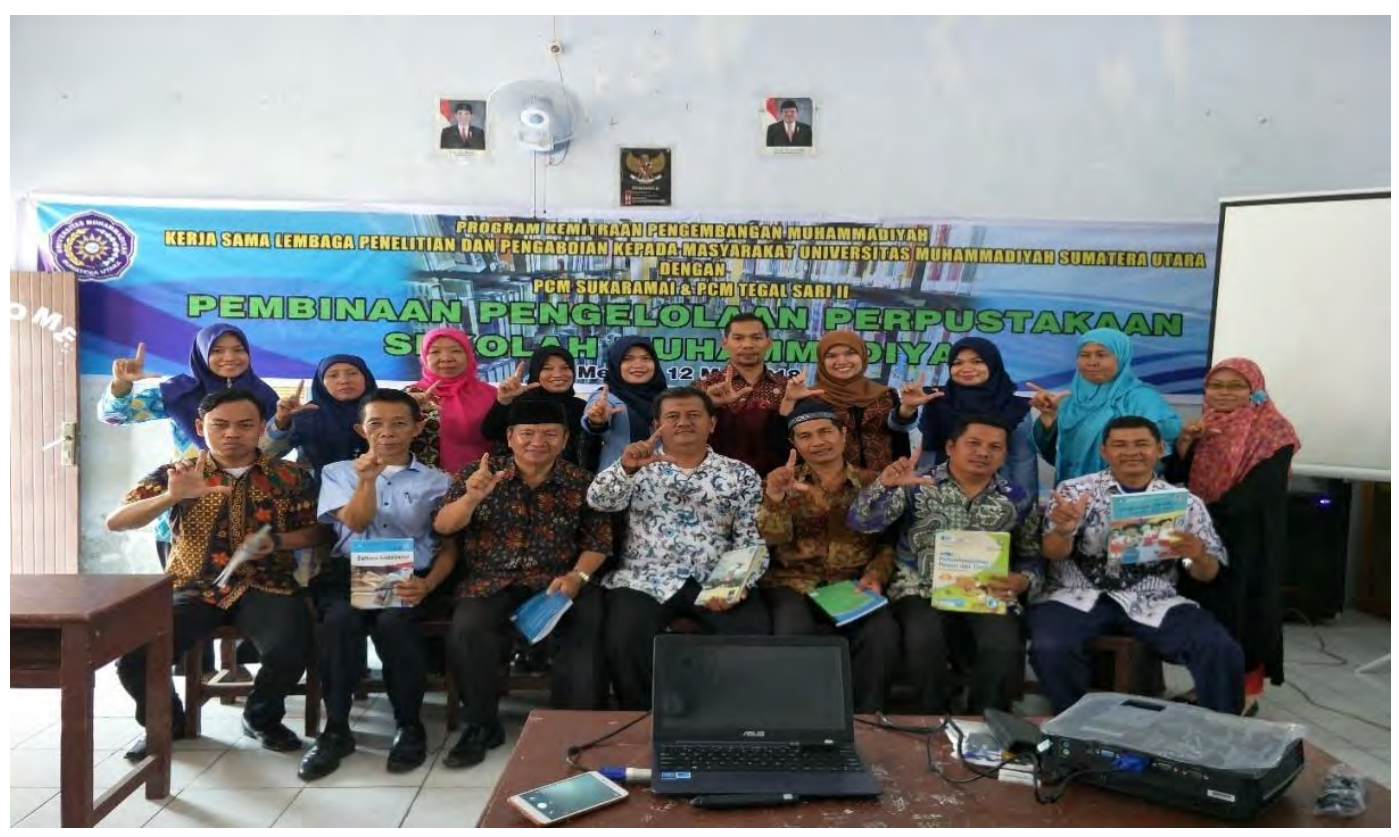

Figure 3. Photo with PCM Sukaramai and PCM Tegal Sari II participants

Related to school library management activities. The teachers who served as managers were facilitated by a number of materials for processing library materials. Activities carried out included practicing inventory of library materials, making book classifications, creating and compiling catalogs and shelving books that the participants had brought in on this coaching activity. This coaching was carried out for two days. The material presented is library management and library material processing. At the end of the evaluation and reflection of the event, there are several things that need to be done by the assisted participants in realizing the management of the school library, namely:

1. Establishment of a school library organization, which must be led by the principal as the person in charge of the school library.

2. Availability of library space that is convenient for students

3. Collaborate with city libraries and provincial libraries to get literature collections.

4. Performing school library processing in accordance with library management standards to achieve superior and competitive school library quality.

5. Monitor and evaluate library management at least every school year.

\section{CONCLUSION}

In general, this coaching activity provided benefits to both partners, namely the PCM Sukaramai and PCM Tegal Sari II, related to the management activities of the Muhammadiyah school library. The results for both partners are, Sukaramai PCM Partner and PCM Tegal Sari II can carry out their roles as school library managers and are skilled in managing the school library. The outcome resulted was not only for the two school library managers, but also for the leaders of the Muhammadiyah school. For the implementing team the lecturer is expected to play an active role in serving in the fields of education, health, social and economics within the Muhammadiyah. The Muhammadiyah community is expected to actively participate in advancing the Muhammadiyah Madrasah in North Sumatra through financial support. For Muhammadiyah School Library as a place of literacy, it is hoped that it can motivate students to be active and actively read in order to increase the knowledge of science. For managers of school libraries are expected to be able to implement management in accordance with library management standards to achieve a superior and competitive library.

\section{References}

Achmad, dkk. (2014). Layanan Cinta ; Perwujudan Layanan Prima Perpustakaan. Jakarta: Sagung Seto

Lasa, Hs. (2009). Manajemen Perpustakaan Sekolah/Madrasah. Yogyakarta: Ombak.

Nugrohoadhi, A. (2016). Personal Branding Perpustakaan. Yogyakarta : Pustaka Nun.

Permendiknas. (2008). Peraturan Menteri Pendidikan Nasional Nomor 25 Tahun 2008 tentang Standar Tenaga Perpustakaan Sekolah/Madrasah. Jakarta: Permendiknas.

Suhendar, Y. (2014). Cara Mengelola Perpustakaan Sekolah Dasar. Jakarta: Prenada. 